\title{
VARIATION AND LIFE STRATEGIES OF THE TRICHOPTERA (INSECTA) LARVAE COMMUNITY IN A FIRST ORDER TRIBUTARY OF THE PAQUEQUER RIVER, SOUTHEASTERN BRAZIL
}

\author{
HUAMANTINCO, A. A. and NESSIMIAN, J. L. \\ Departamento de Zoologia, Instituto de Biologia, Universidade Federal do Rio de Janeiro, C.P. 68044, \\ CEP 21944-970, Rio de Janeiro, RJ, Brazil \\ Correspondence to: Jorge Luiz Nessimian, Departamento de Zoologia, Instituto de Biologia, Universidade \\ Federal do Rio de Janeiro, C.P. 68044, CEP 21944-970, Rio de Janeiro, RJ, Brazil \\ Received February 23, 1999 - Accepted May 24, 1999 - Distributed February 28, 2000
}

(With 5 figures)

\begin{abstract}
The Trichoptera fauna was sampled in a first order tributary of Paquequer River, in the district of Teresópolis, Rio de Janeiro State. Quantitative samples of litter from pools, litter from riffles, sand, and stones were taken on each season from February 1991 to February 1992.The life cycles of common genera were categorized into three groups of biological strategies. The largest group represented the general profile of the community, in which ultimate instar larvae were predominant in spring and the younger ones in summer. Probably, emergence and oviposition occur in spring.
\end{abstract}

Key words: Trichoptera, larvae, life strategies, streams, Atlantic Forest.

\section{RESUMO}

\section{Variação e estratégias de vida da comunidade de larvas de Trichoptera (Insecta) em um tributário de primeira ordem do Rio Paquequer, Sudeste do Brasil}

Na seção de primeira ordem do Rio Paquequer, Teresópolis, RJ, foram tomadas amostras de 4 tipos de substrato: litter depositado em zonas de remanso, litter retido em zonas de correnteza, pedra e areia. De cada tipo foram coligidas 5 amostras em cada estação do ano, de fevereiro de 1991 a fevereiro de 1992. Através de dados de freqüência e biomassa de cada gênero, alguns aspectos da história de vida foram inferidos. Com base nesses dados, foram separados três grupos estratégicos. O maior deles reflete o perfil geral da comunidade, no qual os últimos estádios larvais foram predominantes na primavera e os estádios iniciais, no verão. Provavelmente, a emergência e a oviposição ocorrem na primavera.

Palavras-chave: Trichoptera, larvas, estratégias de vida, riachos, Mata Atlântica.

\section{INTRODUCTION}

The knowledge of life cycles of the aquatic insects is essential for understanding most of the ecological features of this fauna. Wiggins (1996) pointed out that most of the Trichoptera in temperate latitudes complete a generation every year. According to Hynes (1970), the time of emergence is under the dual control of temperature and length of the day, and presumably the relative importance of these factors varies from place to place.

When compared with temperate areas, tropical habitats present smaller variations in their climatic factors, and they are generally considered less seasonal to many organisms (MacArthur, 1972 
apud: McElravy et al., 1982). According to Yule \& Pearson (1996), there are few seasonality studies on Trichoptera carried out in tropical streams with a humid-dry regime. These studies are based only on data of adult emergence (McElravy et al., 1982 and Benson \& Pearson, 1988; Dudgeon, 1988; Statzner, 1976; apud: Yule \& Pearson, 1996) and report similar patterns which are mostly, seasonal.

In the neotropics, Wolf et al. (1988), in a study concerning the emergence of aquatic insects in Colombia, found that the largest emergence came, generally, after the high pluviosity periods and they observed that temperature and rain seemed to be the main regulatory factors. Flint \& Masteller (1993), working in a stream in Puerto Rico, found that distinct correlations did not exist between the pattern of pluviosity and the emergence of Trichoptera. Although they observed that some seasonality seemed to occur in the flight periods of some species, the most abundant ones were present throughout the year. In Brazil, Oliveira \& Froehlich (1997), studying the fauna of Trichoptera in a stream of the cerrado region in the State of São Paulo, found that for Leptonema spp. and
Smicridea spp. the distribution of larval sizes indicated multivoltine life cycles. However, the seasonal abundances varied, showing that the regime of precipitations, and in a smaller degree the temperature, caused a certain seasonality.

The goal of this work is (1) to analyze the populational variations of the most abundant Trichoptera genera in a section of first order of a river in the montane Atlantic Forest area of southeastern Brazil and (2) the relation between environmental factors and life cycles.

\section{STUDY AREA}

The sampling was carried out in a first order tributary of the Paquequer River (ca. 1,100 m high), Teresópolis (22 $24^{\prime} 44^{\prime \prime} \mathrm{S}$ and $\left.42^{\circ} 57^{\prime} 56^{\prime \prime} \mathrm{W}\right)$, State of Rio de Janeiro (Fig. 1). The abundant riparian vegetation maintains most of the stream under shade. The stream width ranges from about $0.5 \mathrm{~m}$ to $2.5 \mathrm{~m}$ and its bed is constituted mainly by sand, pebbles and rocks. The allochthonous organic matter (litter), is retained in riffles or deposited in pools.

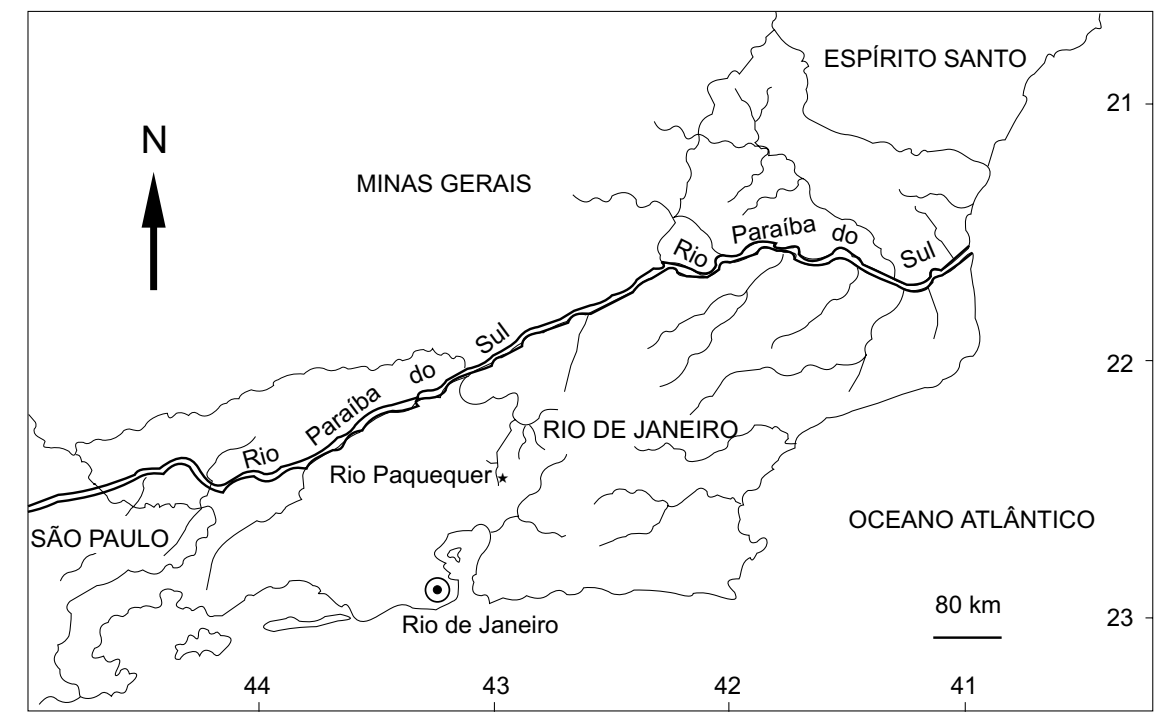

Fig. 1 - Map of the State of Rio de Janeiro showing the location of the area of studies (Rio Paquequer, Teresópolis). 


\section{MATERIAL AND METHODS}

Twenty samples were taken for the quantitative sampling in each season from February 1991 to February 1992. The analyzed months were February, April, July, and October 1991 and February 1992, totalizing 100 samples. The sampling area of each collection was approximately $1.25 \mathrm{~m}^{2}$. Four substrate types were considered: sand, litter retained in riffles, litter deposited in pools, and stones. Five samples were taken from each substrate, using a Surber dredge $(0.3 \mathrm{~mm}$ mesh) for stones and a D-net (1 mm mesh) for the other substrata, both with $0.05 \mathrm{~m}^{2}$ of collecting area. The collected material was fixed in $4 \%$ formaldehyde and conserved in $80 \%$ ethanol.

The collected material was fixed, separated and counted under a stereomicroscope (160x max.). The species or morphospecies were identified with the keys and diagnoses of Angrisano (1995), Wiggins (1996), and the works of Flint (1969), Flint \& Bueno-Soria (1982), Flint \& Wallace (1980), Guahyba (1981), and Holzenthal (1988a,b). Comparisons with deposited specimens in the Museu Nacional (UFRJ, Rio de Janeiro) were made to confirm some identifications. Part of the material was identified with the help of prof. R. Holzenthal, (University of Minnesota) and prof. R. Guahyba (Museu Nacional, UFRJ).

Early instar larvae that did not allow a reliable identification were grouped in the family category. The larvae with very low frequencies were not considered in the statistical analysis.

The biomass of the larvae was estimated using the humid weight of the fixed material. The individuals of each species or morphospecies were separated into size classes. For each size class of each species a number of individuals (10 in average) was weighed in an analytic lever $(0.1 \mathrm{mg}$ of accuracy) to obtain the medium weight value (Nessimian, 1995). The larvae were weighed without their cases.

At each collection, temperature, $\mathrm{pH}$, dissolved oxygen, electric conductivity, and discharge were taken. A mercury thermometer was used to measure the water temperature. The $\mathrm{pH}$ values were obtained with the aid of a portable $\mathrm{pH}$ meter (Analion). The values of dissolved oxygen were measured by the method of Winkler (Brower $\&$ Zar, 1977). The values of electric conductivity of the water were measured with a portable conductivimeter (Analion). The time a floating object took to cover a fixed distance in a stream section with known depth and width was used to measure the discharge.

In order to verify the relations among the most abundant genera, in regard to their life cycles and strategies, the covariance was quantified among all pairs of values of a matrix that contained the frequency and biomass percentages. The Pearson correlation coefficient was used (Ludwig $\&$ Reynolds, 1988). The values of the obtained covariance were used in Cluster Analysis, by the UPGMA method (Sneath \& Sokal, 1973).

\section{RESULTS}

\section{Environmental variables}

The values of the physical and physicalchemical variables considered in the present study showed that the atmospheric temperatures were similar in the summer and in the autumn of 1991. The lowest temperatures, as expected, occurred in the winter. The summer of 1992 presented lower temperatures than those of the previous year. The water temperature accompanied the atmospheric one in its general profile.

The $\mathrm{pH}$ values were lightly acid and with little variation. The largest value occurred in the autumn of 1991 (5.8), and the smallest in the summer of 1992 (4.9). The dissolved oxygen concentrations presented the largest value in autumn (11.25 mg. $1^{-1}$ ) decreasing until February of 1992 (5.7 $\left.\mathrm{mg} . \mathrm{l}^{-1}\right)$. The electric conductivity varied a little during the period of study. It presented a larger value in the spring of $1991\left(21.3\left(\mathrm{mS} . \mathrm{cm}^{-1}\right)\right.$ that is explained by the largest amount of material carried during the first rains after the dry period (winter). The discharge varied between $0.039 \mathrm{~m}^{3} . \mathrm{s}^{-1}$ (autumn of 1991) and $0.006 \mathrm{~m}^{3} \cdot \mathrm{s}^{-1}$ (winter of 1991), reflecting the pluviosity and separating two different periods (rainy and dry).

\section{The community composition and the populational variation of the most abundant groups}

A total of 2.582 larvae (total weight of $10.4 \mathrm{~g}$ ). belonging to 9 families and 20 genera were analyzed. The families Leptoceridae (60.14\%), with the genera Nectopsyche (35.36\%), and Triplectides (16.65\%), and Hydropsychidae (22.45\%), with the 
genus Smicridea $(18.90 \%)$ were the most abundant.

Phylloicus (Calamoceratidae). The larvae of this genus occurred during the whole year. The frequency and biomass peaks appeared in winter, corresponding to the months of drought. Larger larvae were observed in spring, coinciding with the increase in discharge and possibly with adult emergence and oviposition. In the following season, as expected, the smaller larvae were the predominant (Fig. 2).

Helicopsyche (Helicopsychidae). The larvae of this genus, which occur typically in areas with high current, were collected in the stony substratum and retained litter. Larger frequency and biomass values were observed in the summer of 1992. The smaller larvae occurred in larger numbers in the autumn, coinciding with the largest discharge. In the following months the growth of the biomass was verified up to spring, when the developed larvae prevailed and probably adult emergence and oviposition happened. The life cycle seems to be slow and univoltine (Fig. 2).

Atopsyche (Hydrobiosidae). The larvae occurred mainly in the autumn, the season of larger discharge, and were absent in the winter samples. This genus seems to present a short cycle, with more developed larvae and a biomass peak in the summer of 1991 and a prevalence of young larvae occurring in the following season, when the frequency peak occurred. Adult emergence and oviposition possibly took place before the beginning of the abundant rains of the autumn of 1991 (Fig. 2).

Blepharopus (Hydropsychidae). The largest frequency of the larvae coincided with the season of larger pluviosity. The population seems to show an annual cycle. In the summer the less developed larvae prevailed, while in the autumn and in the winter the larger ones were more numerous. The oviposition seems to coincide with the spring rains, since the frequency of small larvae increases quickly from spring to summer (Fig. 2).

Leptonema (Hydropsychidae). This is one of the genera with a larger contribution to the community biomass. The graphs of frequency and biomass percentages of the larvae of Leptonema do not show, as in most of the other genera, a clear prevalence of small or big larvae in a given season. However, a larger amount of larvae both small and big was found, in autumn and winter, while in spring only an individual of medium size was collected. In the summer a very reduced number of small larvae was collected (Fig. 2).

Smicridea (Hydropsychidae). This was the most important genus in substrata submitted to high-speed currents (retained litter and stones). The largest frequency values were obtained in autumn. The same happened with the biomass values. The largest larvae prevailed in the summer of 1991 and the smallest ones, in autumn. It is probable that oviposition happened in the beginning of the rains (Fig. 2).

Atanatolica (Leptoceridae). The presence of these larvae was closely related to the summer. In the summer of 1991 small larvae prevailed. In the following seasons, they did not appear in the samples. In the summer of 1992 grown larvae occurred. The cycle can be considered slow (Fig. 2).

Nectopsyche (Leptoceridae). This very abundant genus constituted $1 / 3$ of the collected larvae. They presented a frequency peak in winter and a biomass peak in spring. The small larvae predominated in winter and the large ones in spring, indicating summer and autumn as the probable season of adult emergence (Fig. 2).

Notalina (?) (Leptoceridae). In this genus there was a predominance of larger larvae for almost the whole study period, except in the summer of 1992, when the smallest ones prevailed. The largest peak, both in frequency and biomass, happened in winter. Probably, as in some previous groups, the oviposition are related to the first rains in the spring (Fig. 3).

Oecetis (Leptoceridae). As in other Leptoceridae, these larvae were strongly associated to the litter retained in riffle areas. In summer and autumn the population was constituted for the most part by small larvae. In winter, the frequency and biomass peaks coincided. In the following season, the larvae reached their largest sizes and the adult emergence and oviposition probably occurred (Fig. 3).

Triplectides (Leptoceridae). The larvae of this genus, as the above mentioned Nectopsyche, were the most abundant in the deposited litter. An analysis of the populacional fluctuation graphs suggests that they apparently avoid competition by means of temporal segregation. 

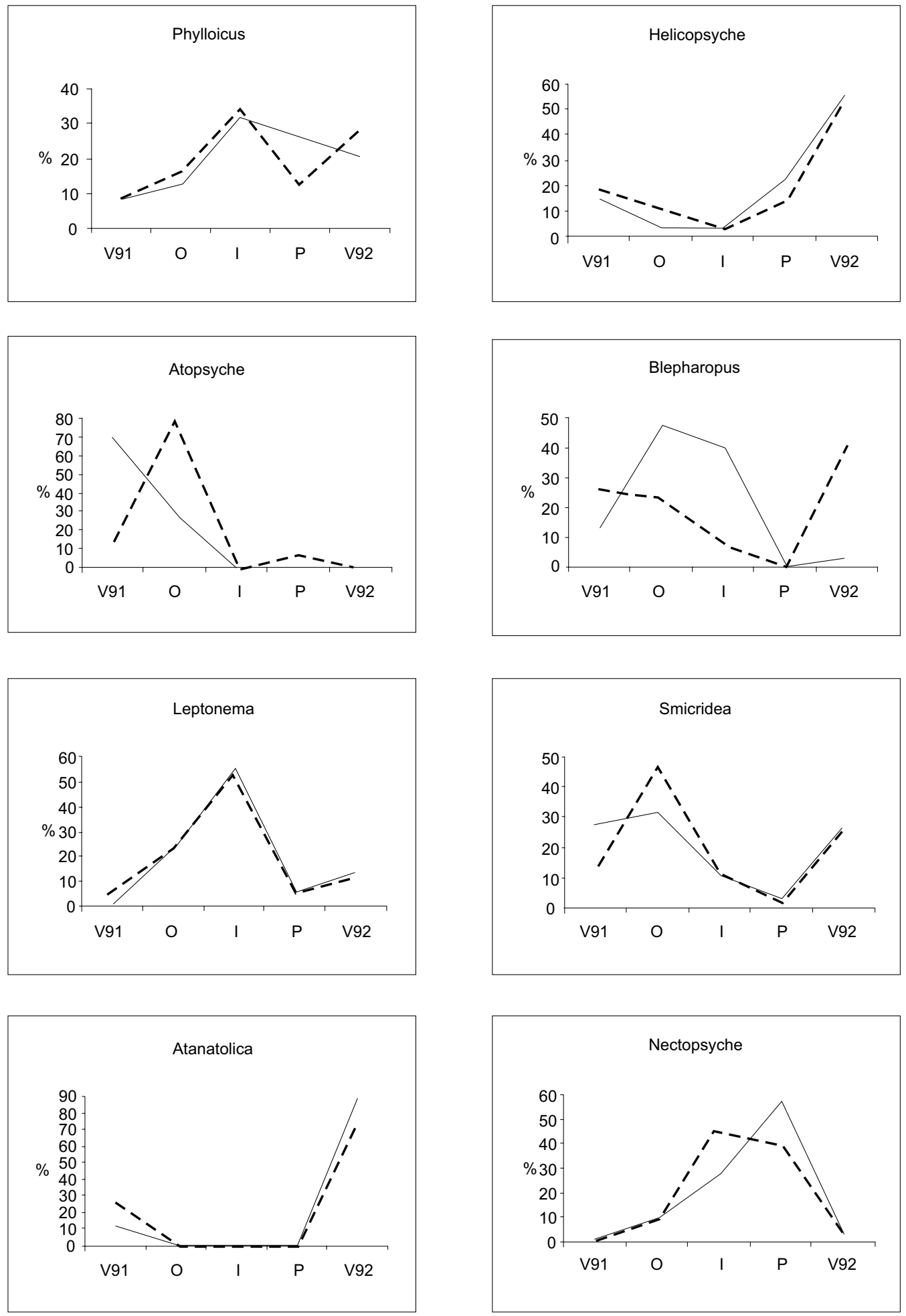

Fig. 2 - Frequency (---) and biomass (- - ) percentages of Trichoptera larvae in a first order tributary of Paquequer River, Teresópolis, RJ, in the study period. V91 - summer of 1991; O - autumn; I - winter; P - spring; V92 - summer of 1992. 

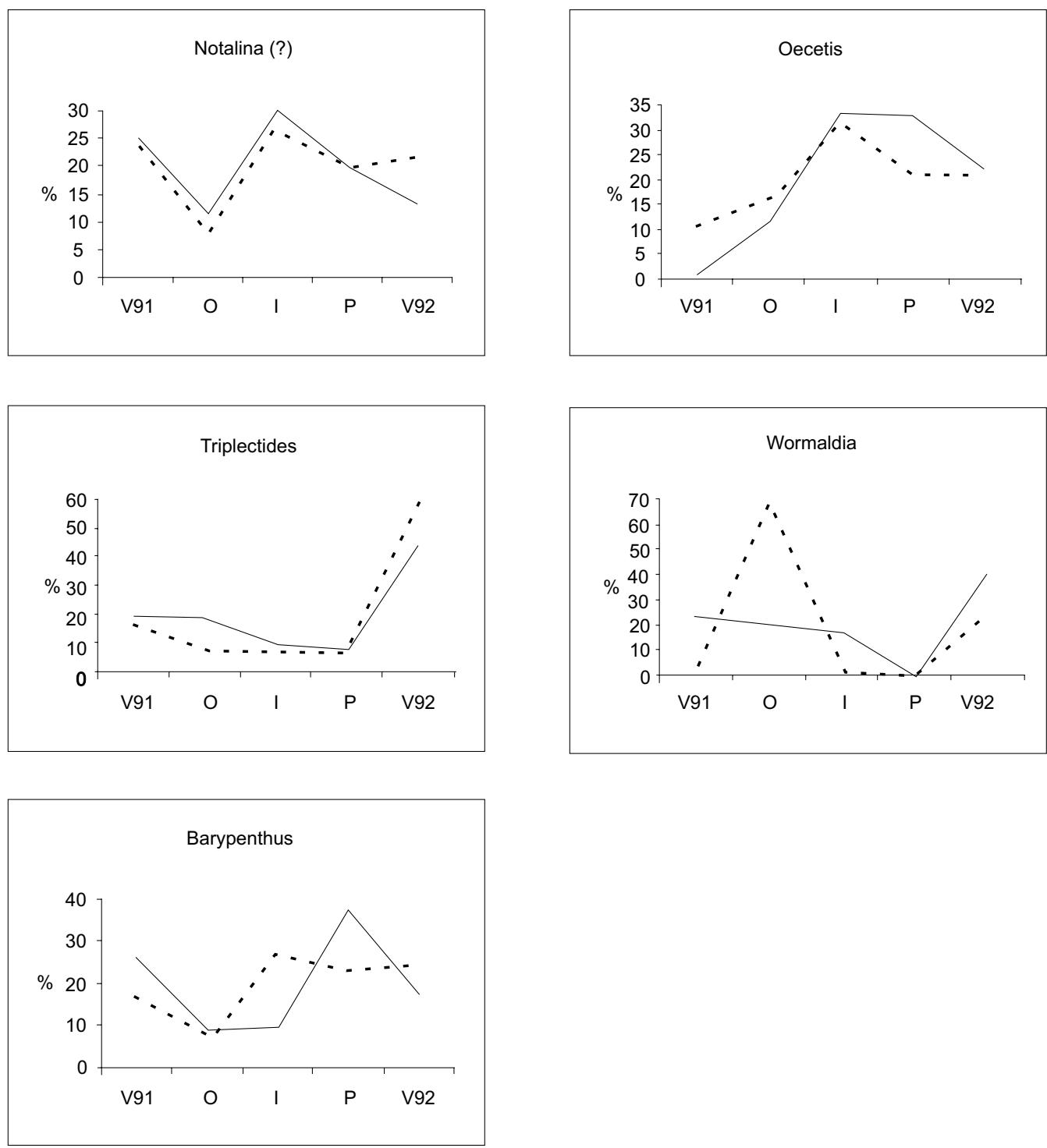

Fig. 3 - Frequency (---) and biomass (- - ) percentages of Trichoptera larvae in a first order tributary of Paquequer River, Teresópolis, RJ, in the study period. V91 - summer of 1991; O - autumn; I - winter; P - spring; V92 - summer of 1992.

The largest values in frequency and biomass occurred in the summer of 1992. Developed larvae prevailed in autumn and the more young ones in the summer of 1992. Univoltinism probably occurs (Fig. 3).

Barypenthus (Odontoceridae). The larvae of this genus are of large size, contributing with more than $50 \%$ of the community biomass. The frequency peaks and biomass did not coincide in time. The former happened in winter, when the smaller larvae also prevailed. The latter happened in spring. The rains that occurred in spring apparently influenced the adult emergence and oviposition, a fact that can be noticed due to the prevalence of young larvae in the following summer (Fig. 3).

Wormaldia (Philopotamidae).These larvae were met only in substrata submitted to high currents. They are associated to autumn, the season of larger discharge. 
Small larvae were collected only in autumn, coinciding with the frequency peak. Adult emergence and oviposition appear to have occurred in the begining of the rains of the autumn of 1991, when the larger larvae prevailed (Fig. 3).

\section{Relation between life cycle and environment}

The whole Trichoptera community presented an increase in the frequency of larvae from the summer to the winter of 1991 . The frequency then started to decline, reaching its smallest value in the spring. From the spring to the summer of 1992 an increase in the frequency was verified, so that the peak was achieved in the latter season. The biomass presented its smallest value in autumn, starting then to grow until the spring (the largest value found).

As printed out above, during autumn and winter the community grows both in frequency and biomass. In these seasons, young larvae are predominant. In the spring the frequency curve goes down abruptly, while that of biomass increases. In this season larger larvae prevail and, probably, adult emergencies and oviposition of most of the species occur, resulting in the predominance of young larvae in the following season (Fig. 4).

The cluster analysis applied to the frequency and biomass percentages of 15 taxa resulted in the recognition of two main temporaly groups that denote different life strategies: the winter-spring group and the summer-autumn group.

The winter-spring group contains larvae that reach their largest sizes in spring and they follow the general pattern of the community (Nectopsyche, Phylloicus, Barypenthus, and others). The summerautumn group is divided into two branches: the summer group, which is characterized by the small number of individuals during autumn, winter, and spring, but presents peaks of frequency and/or biomass in summer (Helicopsyche, Triplectides, and Atanatolica); and the autumn group, characterized by a strong prevalence of small larvae in the autumn. The adult emergence and oviposition of eggs should have happened in the summer of 1991 (Smicridea and Wormaldia) (Fig. 5).

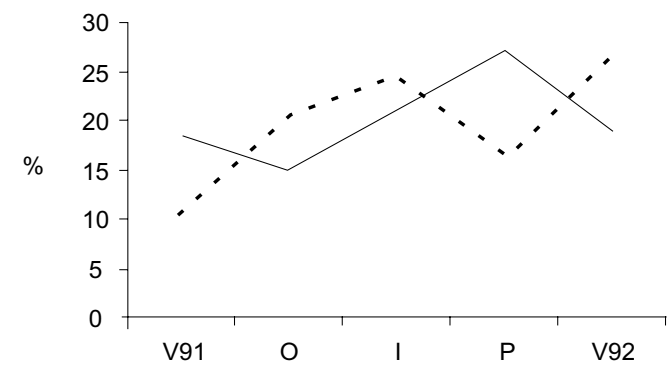

Fig. 4 - Frequency (----) and biomass (- -) percentages of the Trichoptera larvae community in a first order tributary of Paquequer River, Teresópolis, RJ, in the study period. V91 - summer of 1991; O - autumn; I - winter; P - spring; V92 - summer of 1992 .

\section{DISCUSSION}

\section{Environmental variables}

As in other studies carried out in first order streams of tropical zones, the values of the water temperature presented a small variation. Several authors, as Wolf et al. (1988), found that the temperature does not seem to be a fundamental factor in the structure and distribution of aquatic organisms in the tropics. However, the temperature can play na important role in several processes involving the microorganisms and aquatic invertebrates. Nolen \& Pearson (1993), working in a stream of the tropical humid forest in Australia, found that a shredder species of Calamoceratidae, processed leaves more quickly when temperatures were higher during summer.

A variation was observed in the values of dissolved oxygen. This variation is directly related to discharge, as the studied area is fundamentally of high pluviosity. The values are close to saturation. 


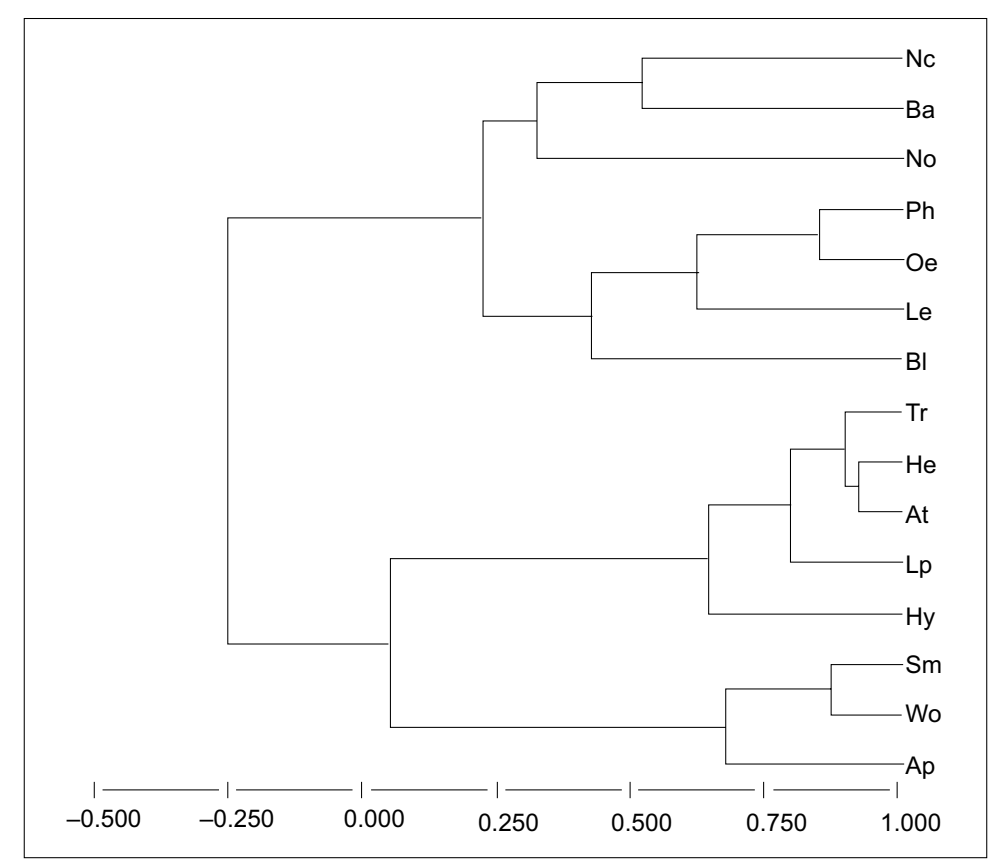

Fig. 5 - Dendrogram based on the values of Pearson correlation coeficient $(r=0.497, p=0.05)$ calculated among the most frequent genera in the sampling during the study period. At - Atanatolica; Ap - Atopsyche; Ba - Barypenthus; B1 - Blepharopus; He - Helicopsyche; Hy - Hydropsychidae; Le - Leptonema; Lp - Leptoceridae; Nc - Nectopsyche; No - Notalina; Oe - Oecetis; Ph - Phylloicus; Sm - Smicridea; Tr - Triplectides; Wo - Wormaldia.

The $\mathrm{pH}$ values were lightly acid, with a medium value of 5.3. Although low $\mathrm{pH}$ values are related, in several cases, with smaller diversity of species and lower productivity (Ward, 1992), studies in New Zealand (Winterbourn \& Collier, 1987 apud: Ward, 1992) in streams of natural acidity showed that only values lower than 4.6 were able to reduce the taxonomic richness to $50 \%$.

The discharge data are correlated directly with the pluviosity which is high in summer and lower in winter. These features suggest an unimodal pluviosity regime.

\section{Seasonality of the biological cycle}

For most of species of Trichoptera, autumn and winter are seasons when the population growth is constant with a prevalence of young larvae, which exploit the food carried by the current in autumn, and the leaves deposited in pools, when the smaller pluviosity results in good quality detritus. In the spring larger larvae prevail, coinciding with the beginning of the rains after the months of drought and the increase of the water temperature (although slight). The adult emergences that happen in this period would be associated to a syncronism (Oliveira, 1996) as an adaptation to the environment, favouring, due to the new rains, the oviposition and dissemination of the eggs and larvae.

According to Oliveira (1996), who worked on the Trichoptera community in streams of the das Almas river basin (Goiás) in the months subsequent to the colder temperatures and before the beginning of rains (specifically the months of September and October), an evident increase in the amount of all instars occurred, suggesting the possibility of a "regulator period" in the distribution of those taxa. According to Flint (1991a), who obtained data on the emergence of many taxa during one year in Colombia, the emergence in Trichoptera is clearly correlated with the rains in the study area, where the smallest pluviosities happen in January and there are peaks in April and in October (bimodal pattern). The emergence also presented peaks from April to May. Undoubtedly, some specific event, which happens in the period February-March and 
is related with the rain, starts the emergence process that attains a peak one or two months later.

With regard to the strategic groups, the winter-spring group, which follows the community general profile, seems to be synchronized with the adult emergence in favorable climatic conditions (spring), as well as with the temperature increase, the beginning of the rains, and the input of organic matter in the stream. In this group shredder larvae (e.g., Nectopsyche and Phylloicus) and predators as (e.g., Barypenthus and Oecetis) prevail. The larvae of the summer group would be synchronizing their frequency peaks with the largest periphyton availability in this season. In this group we have the scrapers Helicopsyche and Atanatolica. The life cycles included in the autumn group seem to synchronize the new larvae with the largest discharge observed in the study period. Smicri$d e a$, the collector of largest frequency in the community, is a member of this group.

Aknowledgments - The authors thank Prof. Dr. Leandro G. Oliveira (UFG), Prof. Dr. Alcimar L. Carvalho (Museu Nacional, UFRJ), Profa. Dra. Marcia S. Couri (Museu Nacional, UFRJ), and Prof. Gabriel Mejdalani (Museu Nacional, UFRJ) for useful comments and suggestions on the manuscript. This study was suported by FAPERJ, FUJB, and $\mathrm{CNPq}$.

\section{REFERENCES}

ANGRISANO, E. B., 1995, Insecta Trichoptera, pp. 1199-1237 In: E. C. Lopretto \& G. Tell (eds.) Ecosistemas de Aguas Continentales: metodologias para su estudio, v. III, xvii+897-1401 p., Ediciones Sur, La Plata.

BROWER, J. E. \& ZAR, J. H., 1977, Field and Laboratory Methods for General Ecology. Wm.C. Brown pub. Dubuque, 2a ed., 226p.

FLINT, O. S., Jr., 1969, Studies of Neotropical Caddisflies, VIII: Immature Stages of Barypenthus claudens. Proc. Ent. Soc. Wash., 171(1): 24-28.

FLINT, O. S., Jr., 1991, Studies of Neotropical Caddisflies, XLV: The Taxonomy, Phenology and faunistics of the Trichoptera of Antioquia, Colombia. Smithson. Contr. Zool., 52: 1-113.

FLINT, O. S., Jr. \& BUENO-SORIA, J., 1982, Studies of Neotropical Caddisflies XXXII: The immature stages of Macronema variipenne Flint \& Bueno, with the division of Macronema by the resurrection of Macrostemum (Trichoptera:Hydropsychidae). Proc. Biol. Soc. Wash., 95(2): 358-370.
FLINT, O. S., Jr. \& MASTELLER, E. C., 1993, Emergence composition and phenology of Trichoptera from a tropical rainforest stream at El Verde, Puerto Rico. $J$. Kan. Ent. Soc., 66(2): 140-150.

FLINT, O. S., Jr. \& WALLACE, J. B., 1980, Studies of Neotropical Caddisflies, XXV: The immature stages of Blepharopus diaphanus and Leptonema columbianum (Trichoptera: Hydropsychidae). Proc. Biol. Soc. Wash., 93(1): 178-193.

GUAHYBA, R. R., 1981, Contribuição ao estudo dos Trichoptera KYRBY, 1813, na represa dos ciganos, Rio de Janeiro, baseada em larvas, pupas e casas (INSECTA). Dissertação de Mestrado, MN-UFRJ, Rio de Janeiro, 156p.

HOLZENTHAL, R. W., 1988a, Systematics of Neotropical Triplectides (Trichoptera: Leptoceridae). Ann. Ent. Soc. Am., 81(2): 187-208.

HOLZENTHAL, R. W., 1988b, Studies in Neotropical Leptoceridae (Trichoptera), VIII: The Genera Atanatolica Mosely and Grumichella Muller (Triplectidinae: Grumichellini). Trans. Am. Ent. Soc., 114: 71-128.

HYNES, H. B. N., 1970, The ecology of stream insects. Ann. Rev. Ent., 15: 25-42.

LUDWIG, J. A. \& REYNOLDS, J. F., 1988, Statistical Ecology. J. Wiley \& Sons, New York, xviii+337p.

McELRAVY, E. P., WOLDA, H. \& RESH, V. H., 1982, Seasonality and annual variability of caddisflies adults (Trichoptera) in a "non-seasonal" tropical environment. Arch. Hydrobiol., 94(3): 302-317.

NESSIMIAN, J. L., 1995, Composição da fauna de invertebrados bentônicos em um brejo entre dunas no litoral do Estado do Rio de Janeiro, Brasil. Acta Limnol. Bras., 7: 41-59.

NOLEN, J. A. \& PEARSON R, G., 1993, Factors affecting litter processing by Anisocentropus kirramus (Trichoptera: Calamoceratidae) from an Australian tropical rainforest stream. Freswat. Biol., 29: 469-479.

OLIVEIRA, L. G., 1996, Aspectos da biologia de comunidades de insetos aquáticos da ordem Trichoptera Kirby, 1813, em córregos de cerrado do município de Pirenópolis, Estado de Goiás. Tese de Doutorado, Instituto de Biociências da Universidade de São Paulo, São Paulo, ii+120p.

OLIVEIRA, L. G. \& FROEHLICH, C. G., 1997, The Trichoptera (Insecta) fauna of a "cerrado" stream in southeastern Brazil. Naturalia, 22: 183-197.

SNEATH, P. H. A. \& SOKAL, R. R., 1973, Numerical Taxonomy - The principles and practice of numerical classification. W. H. Freeman \& Co., San Francisco, $\mathrm{xv}+573 \mathrm{p}$.

WARD, J. V., 1992, Aquatic Insect Ecology. 1- Biology and Habitat. J. Wiley \& Sons Inc., New York, $\mathrm{xi}+438 \mathrm{p}$. 
WIGGINS, G. B., 1996, Larvae of the North American Caddisfly Genera (Trichoptera). Univ. of Toronto Press, Toronto, 2 $2^{\mathrm{a}}$ ed., xiii $+457 \mathrm{p}$.

WOLF, M., MATTHIAS, U. \& ROLDAN, G., 1988, Estudio del desarrollo de los insectos acuaticos, su emergencia $\mathrm{y}$ ecologia en tres ecosistemas diferentes en el Departamento de Antioquia. Actualidades Biologicas, 17(63): 2-27.
YULE, C. M. \& PEARSON R. G., 1996, Seasonality of benthic invertebrates in a tropical stream on Bougainville Island, Papua New Guinea. Arch. Hydrobiol., 137(1): 95-117. 